How to cite this article:

S. Khalil., Ahmad, R., \& Abdullah, J. S. A (2020). Enforcement status of the poison act 1952 against offences related to Kratom (mitragyna speciosa korth) misuse in Malaysia. UUM Journal of Legal Studies, 11(1), 75-93. https://doi.org/10.32890/ uumjls.11.1.2020.6928

\title{
ENFORCEMENT STATUS OF THE POISON ACT 1952 AGAINST OFFENCES RELATED TO KRATOM (MITRAGYNA SPECIOSA KORTH) MISUSE IN MALAYSIA
}

\author{
'Samihah Khalil@ Halim, Rusniah Ahmad \& \\ Siti Alida John Abdullah \\ School of Government, UUM College of Law, Government and \\ International Studies, Universiti Utara Malaysia \\ ${ }^{1}$ Corresponding author: samihah@uum.edu.my
}

Received: 29/8/2019 Revised: 1/1/2020 Accepted: 8/1/2020 Published: 30/1/2020

\begin{abstract}
The kratom story in Malaysia is a bit intricate. Kratom (Mitragyna speciosa Korth) or by the local name ketum is a local plant where 'mitragynine' (alkaloid in kratom leaves) is listed as a psychotropic substance under the Malaysian Poison Act 1952. The law states that any activity related to possessing, selling, using, transporting, processing, importing, or exporting kratom is considered illegal and can be prosecuted. Interestingly, kratom trees are not illegal plants and no laws in Malaysia forbid the cultivation or the presence of naturally growing kratom. On the prosecution side, the current laws do little to prosecute kratom addicts for rehabilitation due to no available kratom test kits which can assist the enforcement agency to arrest and prosecute kratom addicts. Therefore, the enforcement of law on kratom has been largely applied for transporting, processing and selling. Though the Poison Act cannot stop anyone who wants to plant or grow kratom, there are land laws that prohibit the plantation of kratom on land specified for agricultural purpose, adding a tricky situation to the present circumstances related to kratom. In pharmacology, there is research and demand for the development of
\end{abstract}


kratom, and demands from international pharmaceutical companies for kratom had created an illegal rational economic exploitation of Malaysia's kratom by individuals, resulting in more intricacies to the existing complication. This paper intended to discuss the legal status of kratom in Malaysia which we believe is facing its crossroad. The paper used the rational approach of economic and criminology arguments to establish kratom offences in the northern states of Malaysia, thus offering a review of the current state-of-affair. Police statistics and data on kratom offences were then presented to discuss the current status and its implication.

Keywords: Enforcement, kratom (Mitragyna speciosa Korth), kratom offences, Poison Act, Malaysia.

\section{INTRODUCTION}

The Malaysian government had listed kratom in the Poison Schedule List since the introduction of the Poison Act 1952. In the amendment of Malaysia's Poison Act 1952 in 2003, 'mitragynine', an alkaloid in kratom leaves, is listed as poisonous in the First and Third Schedules under the Poison Act, because it contains psychotropic substances. Under Section 30 (3) of the Poison Act 1952, "Any person who contravenes subsection (3) or any regulation made under this Act relating to psychotropic substances shall be guilty of an offence and shall, on conviction, be liable to a fine not exceeding ten thousand ringgit or imprisonment for a term not exceeding four years or both." The abuse of kratom is punishable with a maximum jail sentence of four years or fines not exceeding RM10,000 or both.

Even with the legal initiatives to classify kratom (mitragynine) as poisonous in the First and Third Schedules (psychotropic substances) of the Poisons Act 1952 of January 2003, the level of kratom abuse has not diminished. This is due to the fact that the enforcement of the Poisons Act 2003 mainly focuses on the possession of kratom rather than consumption (Narcotic officer, personal communication, 2 October 2017). The purpose of the Poisons Act is not to deter consumption and addiction but to control possession and the carrying of poisonous substances.

Kratom (Mitragyna speciosa Korth) or ketum is a tropical plant abundantly grown in Southeast Asia. The fertile soil of the 
northern part of West Malaysia makes kratom trees grow naturally. Traditionally, kratom leaves have been used by local men, particularly in the northern states of Malaysia for medicinal and recreational purposes (Kamarudin and Zoriah 2012). Studies by Chittrakarn, Penjamras \& Keawpradub (2012) and Suwanlert (1975) reported that people in Thailand have used kratom cocktail drinks which are popular for energy boosting and mood altering for many decades. Samihah, Siti Alida and Rusniah (2018) found that kratom use in Malaysia is associated with drug addicts and teenagers who consume kratom drink in their drug-use activities either for opiatereplacement or as social drinks. Thus, the word misuse refers to the consumption of kratom for additional related activities, outside the scope of traditional medicine purposes, as specified under the Act. Chan, Pakian and Rusyidah (2005) identified that mitragynine in kratom is an alkaloid that can trigger the human brain to addiction. The first addiction case in Malaysia appeared in a report by Thuan (1957). In Thailand, Suwanlet (1975 ) reported a series of kratom addiction cases, creating a perception among the public and law enforcement authorities in Malaysia that kratom consumption can lead to addiction to other drugs (Chan, Pakiam, \& Rusyidah, 2005). The proliferation of kratom drink misuse or abuse among the youth in Malaysia is an alarming social problem, especially in the northern states of Peninsular Malaysia. The drink, which is widely taken by older folks for boosting energy and mood altering, has been tried by youth in their social activities. The misuse of mixing kratom drink with dangerous substances, gained its popularity among youth in the northern states of Malaysia. A prolonged use of kratom can cause symptoms of addiction or addiction itself, and nowadays youth are said to be the group most affected by kratom abuse. Kratom abuse among the youth has caused apprehension among parents, schools and community leaders, especially in the northern Malaysian states of in Kedah and Perlis, where kratom grows naturally. The abuse issue is critical since the involvement of youth in its usage is rampant. Most youth misuse kratom by mixing the kratom drink with all sorts of other substances in order to obtain a hallucinatory or opiate-like condition. This scenario is worsening since kratom is easily accesible and cheap (Kamarudin Ahmad \& Zoriah, 2012).

Unlike other drug addicts, kratom addicts' statistics are difficult to get due to many reasons. Firstly, until today, there is no device yet available to detect kratom addicts; therefore, cases on kratom are related to possessing, selling, using, transporting, processing, 
storing, importing, and exporting of kratom, but not using kratom. Moreover, regarding addiction the same Act has its constraint to prosecute any type of kratom users. The current law does little to prosecute kratom addicts for rehabilitation, making the enforcement of the law on kratom to be largely biased toward transporting, processing and selling.

On a positive tone, kratom has some medicinal benefits as claimed by the local people (Samihah, Alida and Rusniah, 2015). According to scientific studies, mytragynine in kratom leaves contains potential opiod-like effects which can be used to treat opioid-withdrawal symptoms (Rosenbaum, Carreiro and Babu, 2012). Mitragynine produces antinociceptive and opiate-like effects (Swogger, Hart, Erowid, Erowid, Trabold, Yee, Parkhurst, and Priddy \& Walsh, 2015). Usage of fresh kratom leaves for the traditional treatment of illness however, has decreased significantly due to the easy availability of numerous modern medicines and therapies as alternatives or substitutes to what has been traditionally used (Tanguay, 2011).

This paper addresses the basic question of whether the enforcement of the Poison Act 1952 contributes to the reduction in the number of kratom addicts. In fact, kratom misuse is gaining popularity following the amendment of the law. The enforcement of the law, rather to deter kratom offences, only led to more illegal economic and social misuse of kratom in Malaysia. Illegal activities related to kratom have an impact on the informal sector and social life through the unlawful export or smuggling at the border. In order to explore the enforcement vitality of the Poison Act, this paper discusses the problem in the light of crime behaviour, enforcement of the law, and registered and investigated criminal offences related to kratom in the state of Kedah, Malaysia, as evidence and finally puts forward a few strategies to reduce kratom-related offences in the country.

\section{Crime Behaviour and Law Enforcement}

The knowledge on criminology is worthwhile to start with. In criminology, Siegel defined public-order crime as "a crime which involves acts that interfere with the operations of the society to function efficiently", i.e. it is a kind of behavior that has been labelled criminal because it is contrary to shared norms, social values, and customs. Robertson (1989) maintains that a crime is nothing more than "an act that contravenes a law". Therefore, deviancy is 
criminalized when it is disruptive and has proved uncontrollable through informal sanctions. Legal scholars note that one of the functions of criminal law is to express a collective sentiment that society disapproves of certain acts, even when these acts are not necessarily dangerous or obviously harmful to an apparent victim (Polinsky \& Shavell, 1997).

Crime is also committed as an individual decision and act. Before the beginning of scientific criminological studies, explanations of crime were based on religious concepts such as sin and evil, not being-God fearing, or based on utilitarianism or 'hedonism', the idea that people calculated the relative likelihood of pleasure and pain in deciding how to act (Chambliss \& Hass, 2012). The classical theory of crime promulgates the principle of personal responsibility and choice in explaining crime behavior (see pioneer work of Jeremy Bentham, 1784-1832, in his "Introduction to the Principles of Morals and Legislation"). Therefore, economists view criminals as reasoning human beings evaluating total circumstances before choosing to participate in acts that violate the law including their own personal circumstances such as experience, need, want, desire and satisfaction. An economical perspective of public law enforcement explains that it can help to maximize social welfare. Social welfare refers to the benefits that individuals obtain from their behavior, less the costs that they incur to avoid causing harm, the cost of catching offenders and the cost of imposing fines and imprisonment.

However, sociological theories put crimes as a social fact; it exists outside the individual traits and variations in human thought and action. Back in the nineteenth century, sociologist Emile Durkheim $(1858$-1917) stated that all aspects of society serve a specific function that contributes to the order of life, and even to crime. Durkheim's studies describe crime as being a product of individuals not being able to obtain goals through legitimate means and he sees crime arising from a "failure to achieve goals which are seen as desirable within the society" (Croall, 1998).

Today crime, intrigued buy the structure of society, develops from various dynamics, relationships and interactions that take place within the social environment and is pathological in nature. Crime occurs because aspects of the social environment are pathological. Pathological conditions include disorganization, strain and culture conflict. Individuals exposed to such conditions will acquire 
patterns of criminal behavior. Whether a crime is justified by using the classical theory of crime such as rational choice or the social structure perspective where crime is seen as an acquired behavior, the principles underlying the enactment of the law are similarly construed.

The "broken window theory" was promulgated by Wilson and Kelling (1982), where in the early 1980s an observation was made by both on an abandoned building in a city. When a window on a building is broken and left in disrepair, it is not long before other windows of the building would be broken. The state of the building with broken windows sends a message to others that no one cares about the building, thus inviting more abuse, and possibly leading to additional crimes. Essentially, it starts a downward spiral of lack of caring and sense of responsibility. In response to this theory, broken windows policing whereby the police focus on law enforcement on smaller crimes to disrupt the cycle, was established. When neighbourhoods are kept under vigilance and stricter control, residents have less motivation to commit crime. This theory links disorder and incivility within a community to subsequent occurrences of serious crimes. The "broken window theory" explains where policing is intended to reduce small crimes in a neighbourhood before it leads to more crime disruption.

Laws and their enforcement are meant to install public order and deter future violation of crimes. In the context of law enforcement, in order to fix crime in a society laws are imposed (Walker, 1977). Under the theory of public enforcement of the law, government agents such as police, prosecutors, regulators, inspectors and auditors are authorities who detect and sanction violators of legal rules (Polinsky, 2005). Laws are designed to protect society from harm and preserve peace and order which are also termed as crimes against public order (Siegel, 2006). However, they are more than aiming at public order and reducing crimes to justify a good law and its enforcement. Polinsky (2005) argues that law enforcement must satisfy social welfare, the expected utility of the agent and society's resources. The Poisons Act is expected to increase the utility of the agent and optimise society's resources through enforcement. Severe penalty for kratom offences, thus can curb illegal kratom activities. Before civil laws were enforced, people lived within the local socio-cultural conscience of a given society in which moral values, 
whether based on religion or tradition, pre-determined an individual is conduct of right or wrong. With the formation of a state, the idea of moral standards was enforced, perpetually, in society, by law or enforcement bodies or social pressure, in order to create and maintain desirable standards of public morality.

Morality became the foundation of many enacted civil laws in the world and should be the ultimate aim of society. Moral and ethical values have been the guiding spirit and principle to the creation of our Federal Constitution and Rukun Negara. Our Vision 2020 aims "to establish a fully moral and ethical society whose citizens are strong in religious and spiritual values and imbued with the highest ethical standards." Morality is often used to justify the regulation of criminal and civil laws of a country. Drugs laws, for example, are laws regulating public morality, safety, health and public interest. The Dangerous Drugs Act made in 1952 covers penal, procedural and evidential matters, as well as regulates the importation, exportation, manufacture, sale and use, possession, cultivation, and the use of premises for certain dangerous drugs and substances. Despite its strict enforcement, drug addiction reached the menacing stage and in 1983 the government had to declare nation-wide 'war' against drugs after the first ever national security declaration to fight the communism threat.

\section{Kratom Offences in Kedah State}

For the purpose of this research problem, kratom offences in the state of Kedah in Malaysia and the promulgation of the Poison Act were taken as case studies to understand the status of the enforcement of law in eliminating criminal incidences. As such, official data from the Narcotic Department on kratom offences in Kedah were collected for the years 2012 to 2016. The Narcotic Department of Malaysia is the principal law enforcement body that takes direct responsibility and keeps statistics on arrest and prosecutions of kratom offences. These records are generally broken down into the confiscation of kratom in the forms of leaves and liquid drinks. Information, related to the offences and the offenders, like administrative jurisdiction of the incidence, and the age and ethnicity of the offenders are recorded as crime statistics.

Tables 1 to 4 and Figures 1 to 3 present information related to kratom offences along with other details about the incidences reported in the state during 2012 to 2016 . 
UUMJLS 11(1), Jan 2020 (75-93)

Table 1: Kratom Offences in Kedah from 2012 until 2016

\begin{tabular}{lcccccc}
\hline \multicolumn{1}{c}{ Kratom Offences } & $\mathbf{2 0 1 2}$ & $\mathbf{2 0 1 3}$ & $\mathbf{2 0 1 4}$ & $\mathbf{2 0 1 5}$ & $\mathbf{2 0 1 6}$ & Total \\
\hline $\begin{array}{l}\text { Kratom leaves } \\
\text { confiscated (in kg) }\end{array}$ & 1,565 & 2,143 & 5,654 & 9,314 & 7,686 & 26,362 \\
$\begin{array}{l}\text { Kratom drinks } \\
\text { confiscated (in litres) }\end{array}$ & 9,072 & 37,243 & 4,182 & 5,493 & 3,353 & 59,343 \\
$\begin{array}{l}\text { Arrest made } \\
\text { (No. of Persons) }\end{array}$ & 779 & 775 & 945 & 907 & 674 & 4080 \\
$\begin{array}{l}\text { Prosecution followed } \\
\text { (No. of Persons) }\end{array}$ & 598 & 590 & 742 & 832 & 621 & 3383 \\
$\begin{array}{l}\text { Kratom leaves } \\
\text { confiscated } \\
\text { (kg per prosecution) }\end{array}$ & 2.6 & 3.6 & 8.0 & 11.2 & 12.4 & 7.8 \\
$\begin{array}{l}\text { Kratom drinks } \\
\text { confiscation } \\
\text { (litres per prosecution) }\end{array}$ & 15.2 & 63.1 & 5.6 & 6.6 & 5.4 & 17.5 \\
\hline
\end{tabular}

Source: Narcotic Department, IPK Kedah, 2017.

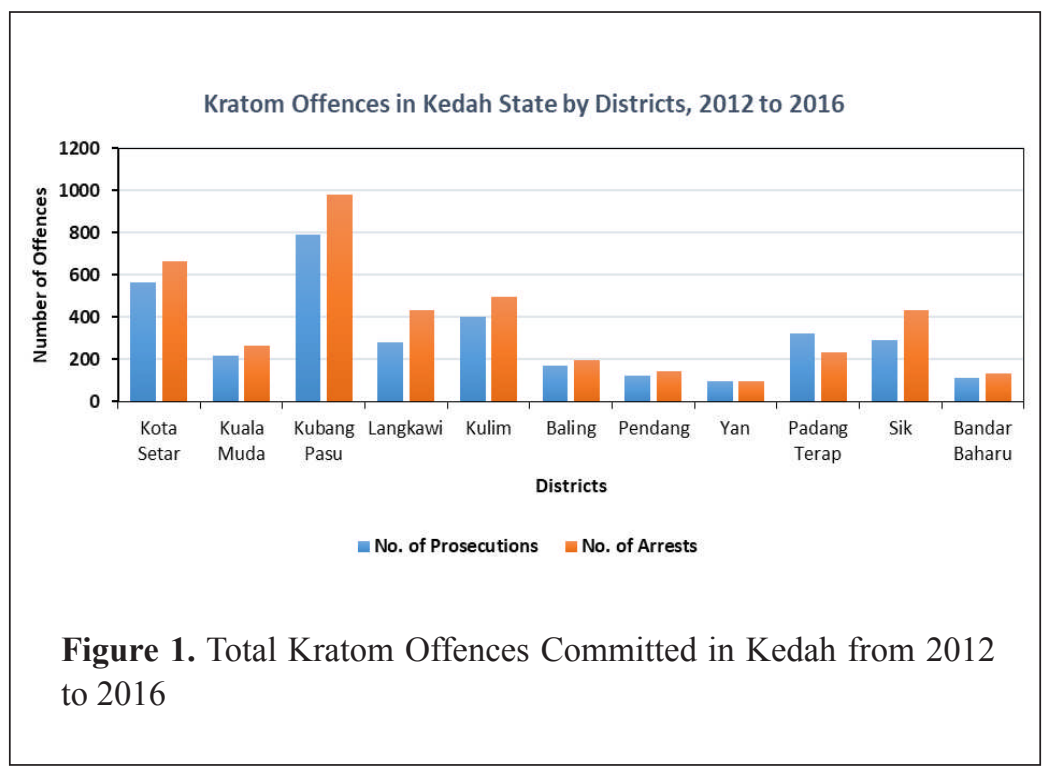


Table 2: Prosecution of Kratom Offences by Age Groups, Ethnicity and Citizenship in Kedah, 2016

\begin{tabular}{cccccccc}
\hline \multirow{2}{*}{$\begin{array}{c}\text { Age } \\
\text { (Years) }\end{array}$} & \multicolumn{4}{c}{ Citizens } & \multicolumn{1}{c}{$\begin{array}{c}\text { Non- } \\
\text { citizens }\end{array}$} & Total \\
\cline { 2 - 5 } $15-19$ & 49 & 0 & 0 & 1 & 3 & 53 \\
$20-24$ & 142 & 0 & 1 & 3 & 18 & 164 \\
$25-29$ & 110 & 0 & 0 & 5 & 12 & 127 \\
$30-34$ & 80 & 1 & 0 & 3 & 5 & 89 \\
$35-39$ & 81 & 1 & 0 & 6 & 4 & 92 \\
$>=40$ & 141 & 0 & 0 & 2 & 4 & 147 \\
Total & 603 & 2 & 1 & 20 & 46 & 672 \\
\hline
\end{tabular}

Source: Narcotic Department, IPK Kedah, 2017.

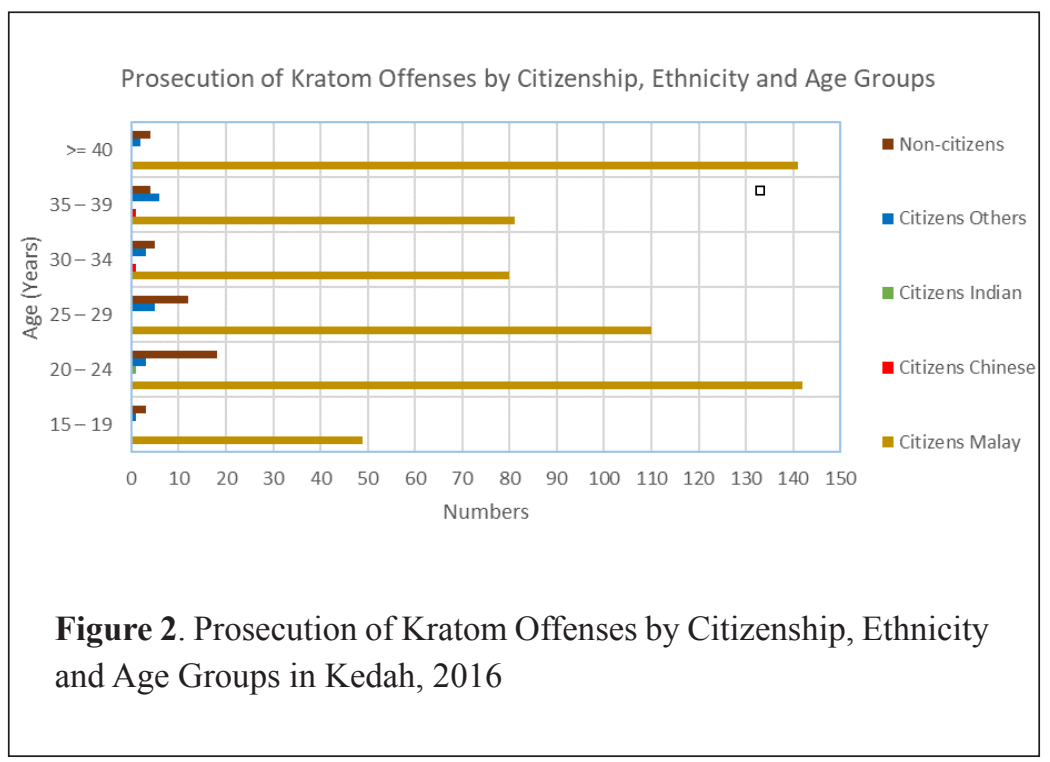


UUMJLS 11(1), Jan 2020 (75-93)

Table 3: Quantity and Value of Kratom Confiscated in Kedah, 2012 to 2016

\begin{tabular}{|c|c|c|c|c|c|c|}
\hline Year & $\begin{array}{l}\text { Quantity } \\
\text { of Kratom } \\
\text { Leaves } \\
\text { (in } \mathrm{kg} \text { ) }\end{array}$ & $\begin{array}{c}\text { Value } \\
\text { (in RM) }\end{array}$ & $\begin{array}{l}\text { Quantity } \\
\text { of Kratom } \\
\text { Drinks } \\
\text { (in 1) }\end{array}$ & $\begin{array}{l}\text { Value } \\
\text { (in RM) }\end{array}$ & $\begin{array}{c}\text { Total } \\
\text { Value } \\
\text { (in RM) }\end{array}$ & $\begin{array}{c}\text { Annual } \\
\text { Change } \\
\text { in Total } \\
\text { Value } \\
(\%)\end{array}$ \\
\hline 2012 & 1,565 & $\begin{array}{r}23,479 \\
(20.6)\end{array}$ & 9,073 & $\begin{array}{r}90,726 \\
(79.4)\end{array}$ & $\begin{array}{r}114,205 \\
(100.0 \%)\end{array}$ & - \\
\hline 2013 & 2,143 & $\begin{array}{r}32,146 \\
(7.9)\end{array}$ & 37,244 & $\begin{array}{r}372,438 \\
(92.1)\end{array}$ & $\begin{array}{r}404,584 \\
(100.0 \%)\end{array}$ & 254.3 \\
\hline 2014 & 5,654 & $\begin{array}{r}84,823 \\
(67.0)\end{array}$ & 4,182 & $\begin{array}{r}41,820 \\
(33.0)\end{array}$ & $\begin{array}{r}126,643 \\
(100.0 \%)\end{array}$ & -68.7 \\
\hline 2015 & 9,314 & $\begin{array}{r}139,711 \\
(71.8)\end{array}$ & 5,493 & $\begin{array}{r}54,930 \\
(28.2)\end{array}$ & $\begin{array}{r}194,641 \\
(100.0 \%)\end{array}$ & 53.7 \\
\hline 2016 & 7,687 & $\begin{array}{r}115,305 \\
(77.5)\end{array}$ & 3,354 & $\begin{array}{r}33,530 \\
(22.5)\end{array}$ & $\begin{array}{r}148,835 \\
(100.0 \%)\end{array}$ & -23.5 \\
\hline
\end{tabular}

Note: Estimated underground transaction values: RM15 per kg of leaves and RM10 per litre of drinks.

Source: Narcotic Department, IPK Kedah, 2017.

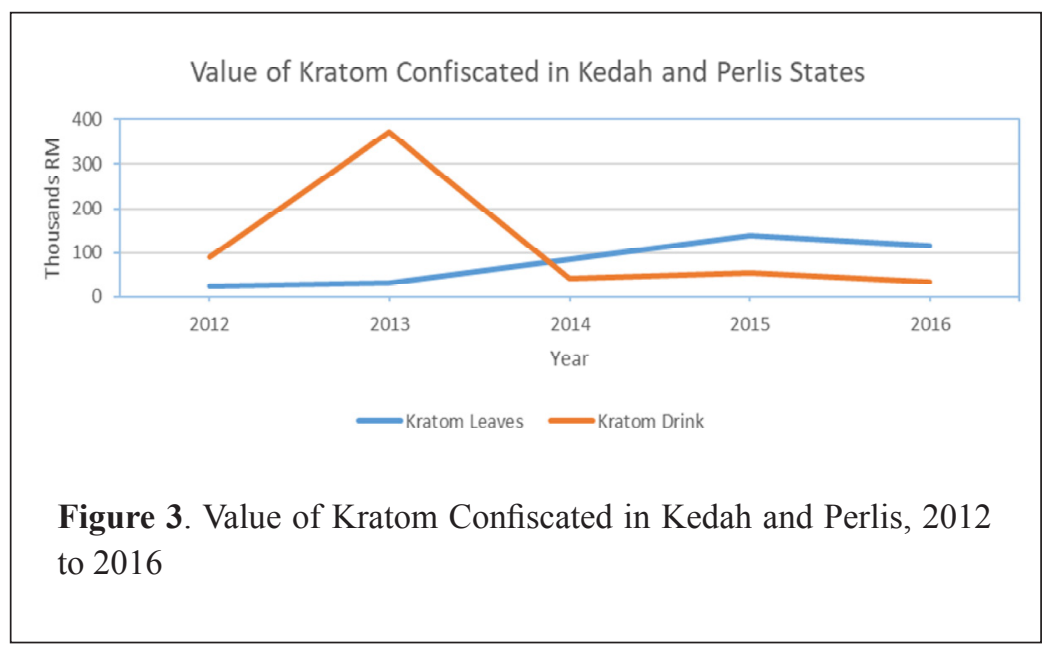


Table 4: Kratom Confiscation at the Borders of Kedah and Perlis, 2015 and 2016

\begin{tabular}{cccccccccccc}
\hline & \multicolumn{4}{c}{ Kedah } & \multicolumn{1}{c}{ Perlis } \\
\cline { 2 - 11 } Year & Total & $\begin{array}{c}\text { State } \\
\text { Border }\end{array}$ & $\begin{array}{c}\text { \% of } \\
\text { Total }\end{array}$ & $\begin{array}{c}\text { Other } \\
\text { Sites }\end{array}$ & $\begin{array}{c}\text { \% of } \\
\text { Total }\end{array}$ & Total & $\begin{array}{c}\text { State } \\
\text { Border }\end{array}$ & $\begin{array}{c}\text { \% of } \\
\text { Total }\end{array}$ & $\begin{array}{c}\text { Other } \\
\text { Sites }\end{array}$ & $\begin{array}{c}\text { \% of } \\
\text { Total }\end{array}$ \\
\hline 2015 & 9,314 & 612 & 7.0 & 8,702 & 93.0 & 9,314 & 5,242 & 56.3 & 4,072 & 43.7 \\
2016 & 7,687 & 484 & 6.3 & 7,203 & 93.7 & 7687 & 6,310 & 82.1 & 1,377 & 17.9 \\
\hline
\end{tabular}

Source: Narcotic Department, IPK Kedah, 2017.

\section{RESULTS AND DISCUSSION}

Statistics from the police department show many interesting facts about kratom offences. Table 1 shows that there was a significant increase in the confiscation of kratom in leaf form for almost every year. In 2014 the quantity of kratom leaves confiscated rocketed to 590 per cent from 2012. This indicates first, that law enforcement was taking note of it and second, there was a rise in illegal activities of kratom. However, for kratom drinks there was a twist scenario. In 2013, kratom drinks confiscated jumped to 37,243 litres, a 400 per cent increase from 2012. Suddenly, in 2014 the kratom drinks confiscated dropped to 4,182 litres, a drop of almost 900 per cent. The drop could be explained by two factors. First, liquid form items are perishable and easy to be discarded. Therefore, for the second point here, crafty and experienced kratom drinks makers took fast decisions. Minutes before the police arrived at the location, they immediately poured the unpacked kratom drinks into the drains, thus eliminating evidence. In contrast, the leaves, were are not easy to be thrown away. Even though they were able to be hidden, the police with search warrants, the could extract the evidence later. Conspirators and their accomplices frequently change the manufacturing places to avoid police detection. Among the common places for raids are village coffee shops, gated houses of kratom plantation owners, abandoned house lots and secluded bush areas. Kratom drinks suppliers or sellers are very much aware of the risks they face. This explains the fluctuation in the amount confiscated during the raids. 
Further, kratom confiscation usually tends to decline because selling and smuggling activities tend to drop after major raids.

Data on arrests and prosecutions given in Table 1 also highlight an important point to ponder. It shows more arrests took place in 2013 and dropped slightly in 2015 . However, the prosecution cases continued to increase for two years and dropped. There are a few possible explanations. Sometimes laws are not fully enforced due to some barriers to enforcement. In many cases the law enforcement officers must make some considerations before they can obtain authorization for a raid. In making that decision the officers will consider how egregious the violation is; resource constraints such as inadequate number of officers to follow up on those identified or reported cases, patrol cars and competing interests of other bigger crimes. Consideration factors for prosecution are different such as which charge is most likely to be committed; whether the person is known to be a repeat offender, the quality of evidence/likelihood of conviction for the offenses, significant chemist reports on materials caught, and expediency of the follow-up investigation. In some cases, the law enforcement officer has some leeway in deciding which offense to charge the violator with. A drop-in prosecution case does not mean that laws were not adequately enforced or lesser enforcement activities. But less enforcement may lead to opportunities for more citizens to be involved in kratom offences and illegal behaviors as well. Data from Table 1 indicates a distressingly rising trend in kratom illegal activities such as possessing, selling, transporting, processing and storing. If per capita value is taken, the value of per kilogram confiscation of kratom leaves increased from $2.5 \mathrm{~kg}$ in 2012 to $12.85 \mathrm{~kg}$ in 2016. This tells us that more kratom was on supply and demand. For kratom drinks in 2013, confiscation per prosecution reached $44.8 \mathrm{~kg}$.

In the Poisons Act 1952 arrest and prosecution on the basis of drinking kratom is legally intricate. One of the factors that contribute to the misuse of kratom is the lack of power to prosecute users. Unlike the testing for drug use, there is no test-kit available for testing mytragynine. Without an effective and viable test-kit to detect the existence of mitragynine alkaloids, an Assistant Commissioner of Police in the legal department (personal communication, 24 January 2014) claimed that the task of proving kratom abuse for prosecution 
remains vague. Thus, the problem of kratom abuse continues to escalate in the northern part of Malaysia with constrained police force authority to prosecute the users. Its spread across the state is illustrated in Figure 1. It shows that the crime though it does not occurr uniformly in different districts of Kedah no district is left out in this regard.

As a result of the increase in demand for kratom and the enforcement not being able to curtail the kratom misuse, illegal kratom activities are an alarming phenomenon in the northern states of Malaysia. The Malay community is more affected in kratom misuse where kratom trees are grown on nearby plots in their residential areas. Planting and ownership of kratom trees are not offences, in contrast to the processing and trading of kratom. Table 2 and Figure 2 show offenders by ethnicity. It was found that Malay youths in the age group of 20 to 29 years were dominating the crime scenario in the state. It was obvious for two reasons. First, most kratom growing areas are populated with an overwhelming Malay majority, and second, Malays as native inhabitants of kratom growing areas have a symbiotic relationship with the plant and its uses. Figure 1, on the arrest and prosecution by districts, shows that the district of Kubang Pasu is the top-ranked district when it comes to kratom offences. Kubang Pasu is among the largest districts, economically quite developed with rapid development, a high population, and with huge muddy-paddy fields with suitable soil for kratom to grow abundantly. Bukit Kayu Hitam, a populated place close to the Malaysia-Thai border is located in this district. Police enforcement on illegal kratom activities in many hot-spots areas in several districts are needed and must be regulated to reduce crimes to providing a sense of public safety and public order. The "broken window theory" explains where policing is needed to reduce crimes in a neighborhood before it leads to more kratom abuse and crime disruption in the neighborhood and other localities. With the available data from the police arrests and investigation cases on kratom in Kedah, more enforcement activities are anticipated on drinks manufacturing, trading and smuggling. Beck and McCue's (2009) idea of "predictive policing" argues that data has the potential to transform law enforcement to enable the police to anticipate and prevent crime instead of simply responding to it. On the other hand, the level of public morality on kratom has not reached the level as intended by the law enforcers. 
The moral standards that the enforcement agencies wish to enforce on the society, through law enforcement or social pressure, are still questionable to create and maintain desirable standards of public morality.

The likelihood of crimes occurring is also contributed by the pathological conditions of the social environment where the crimes take place. The number of crimes is determined not only by the rationality and preferences of would-be criminals but also by the economic and social environment created by public policies, including expenditures on police, punishments for different crimes, and opportunities for employment, schooling, and training programs (Becker 1993). The selling of kratom leaves and drinks generate illicit economic opportunities for citizens who are economically engaged either as laborers and farmers or are unemployed (Samihah, Siti Alida and Rusniah, 2014). In Table 3 we used the police statistics to estimate the economic value of kratom based on confiscated kratom leaves and drinks, and illustrated the same in Figure 3. Bear in mind, that this value could be multiplied if we assume that many illegal kratom activities escaped police detection. Statistics on the smuggling of kratom to neighboring Thailand in Table 4 indicate an illicit economic activity with reference to Kedah and Perlis. Thailand prohibited the growing and cultivation of Kratom in any form back in 1948 but many southern Thais are still accustomed to kratom chewing and the kratom cocktail drink "sii koon rooi" which is popular among the locals. This has created a demand for Malaysian kratom. Demand for kratom has attracted local men, despite the law, to commit kratom illegal activities. If people with rational thinking choose to engage in criminal behaviour, either they are induced by financial gains, or in their calculations, their criminal acts upon being caught can still maximize their benefits over the cost if they are found guilty. The decision to commit crime is strong when the gains are more attractive than the gains from abiding the law. However, the decision to violate the law takes into account the range of constraints and opportunities. The compelling and recurrent need for money among the youth in the "broken window" community prompted them to commit smaller crimes to obtain the money they needed. These youths live in places where kratom is abundant and kratom illegal activities are economically acceptable and known to the neighbourhood. This social acceptance or a symbiotic relation with kratom then contributes to both the number and the type of crime they engage in. 
There are many illegal commercial kratom farms in Kedah and Perlis as detected in the police dossiers, and to curb illegal kratom farming is another intricate matter. There are many different individuals involved in the enforcement process. Their roles and responsibilities are prescribed under the law as being either administrative or criminal, or their authority to enforce them and when they are called may be halted by a few factors. Many cases involving land enforcement indicate that land maters are not always enforced adequately. There are several scenarios that can lead to lack of land enforcement in the kratom issue. Examples are the land enforcement officer knows the violator either personally or professionally, or the illegal kratom farms are politically protected which the enforcement officers do not dare to risk backlash from higher up. This can lead to hesitancy to prosecute. In some cases, laws/ordinances may be unclear or conflict with each other. Others may think that kratom offences are relatively insignificant, therefore, people do not take the crime seriously. If these laws are not adequately enforced when it comes to kratom farms, the authority of law enforcement in this regard is diminished. As a result, citizens' sense of community pride can also diminish.

\section{Strategies to Reduce Kratom Offences}

With regard to enforcement, regular enforcement and efficient penalties are adequate to deter the illegal behaviour. Jacques and Reynald (2012) state that law enforcement objectively can increase individual costs and reduce benefits for offenders. The enforcement agencies can enhance their ability to enforce and prosecute kratom offenders. The judge has to be aware that if the offender has violated the laws previously and insignificant penalty has not deterred the offender, a maximum penalty including prison must be given for serious and repeated offences. Crime can be made less attractive by increasing its cost to individuals and deterring criminals by enacting punishments that are precise and certain. Many studies of crime that use the economic approach argue that optimal marginal punishments can deter increases in the severity of crimes (Becker, 1993). In general, law as a justice corrective tool can be used to reinstate public order as long as it can maintain substantive justice (Badariah Sahamid 2005).

Many state laws and regulations are meant to be command and control (Black, 2002). However, according to Professor Julia Black, 
a new understanding of the law must as well as incorporating other actors or non-law enforcement agencies at the post-enactment stage can greatly contribute to the effective efforts in combatting crimes. There is no law to forbid people from growing kratom but there is a land usage law that can be adequately enforced by the Land and Mines Department to fine paddy landowners who planted kratom on specified land. It may lead to a reduction in the number of kratom farms. In the long run, law and policymakers must seek effective laws and policies regarding kratom which can curb kratom abuse among the youth but will not endanger the kratom species as a part of the biodiversity of the place. Professor Peter John from the London School of Economics (2013), in his "New Directions in the Study of Public Policy", suggests that the policymakers should work together with the law enforcement officers in order to look for sustainability and innovation in the new era of the civilized world taking into consideration the globalized issue and political economy. In the U.S. kratom has been banned in several states but Henningfield and Faith (2018) proposed to the Food and Drug Administration to review the scheduling of kratom as there were about three million users of kratom whom showed no potential for kratom abuse but rather used kratom for medical reasons. The dynamics, relationships and interactions that take place within the social environment must be well considered (Chambliss and Hass, 2012). Providing in-depth education about the laws and ordinances that apply to kratom crimes, the potential penalties, and the authority of different entities to enforce the laws are critical to improve the civic-minded. Educate local people and landowners about the kratom law and the effects of kratom abuse on society. Poor perception of the public on kratom must be changed and they must be educated with information and knowledge about kratom. It may be a difficult task but with coordinated enforcement from many agencies and the correct political will, we can build a community who trust and respect the laws. Many scientific studies have been conducted to study the benefits of kratom to human beings. A study by Prozialeck, Jivan and Andurkan (2012) is an example of how kratom has received attention among pharmacokinetics who study mitragynine speciose is reaction to human metabolism. A wiser move is to consider all social, economic, political and medicinal perspectives related to the issue of kratom. Poppy plantation and cultivation in India are an example has existed since the nineteenth century and it is governed 
by laws (Richards, 2001). However, before any regulated cultivation of such plants is started a detailed study of the ongoing controlled farming is essential to design the control mechanism and to avoid possible ill effects.

\section{CONCLUSION}

Enforcement on kratom related offences is under the jurisdiction of the Poison Act 1952, implemented largely by the police department. However, the issue of kratom misuse and offences must be addressed by all parties, i.e. law and policymakers, parents, the immediate family and the community. Coordination of all parties is needed to improve the quality and quantity of the enforcement work done by the authority. Any changes in the law and order must be duly considered and most importantly, any new law must be effective enough to tackle the issue at hand.

\section{ACKNOWLEDGEMENT}

This project was financially supported by the Malaysia AntiDrugs Agency. The authors would like to thank the Department of Narcotic, Ibu Pejabat Polis Kontigen (IPK), Alor Setar and the Legal Deparment, PDRM, Bukit Aman, Kuala Lumpur for their cooperation. Also, the authors would like to thank Prof Ravindra Nath Vyas, Prof. Phang Siew Nooi and Prof. Mustafa Ali Mohamed for their inputs on this project.

\section{REFERENCES}

Badariah Sahamid. (2005). Jurisprudens dan teori undang-undang dalam konteks Malaysia. Petaling Jaya: Sweet \& Maxwell Asia.

Beck, C., \& McCue, C. (2009). Predictive policing: What can we learn from Wal-Mart and Amazon about fighting crime in a recession? Police Chief, 76(11), 18.

Becker, G. S. (1993). Nobel lecture: The economic way of looking at behavior. Journal of Political Economy, 101, 385-409. 
Chan, K. B., Pakian, C., \& Rusyidah A. Rahim. (2005). Psychoactive plant abuse: The identification of mitragynine in ketum and in ketum preparations, Bulletin of Narcotics, LVII (1 and 2), 249-256.

Chambliss, W. J., \& Hass, A. Y. (2012). Criminology: Connecting theory, research \& practice. New York: McGraw-Hill.

Chittrakarn, S.,Penjamras, P., \& Keawpradub, N.(2012). Quantitative analysis of mitragynine, codeine, caffeine, chlorpheniramine and phenylephrine in a kratom (Mitragyna speciosa Korth.) cocktail using high-performance liquid chromatography. Forensic Science International, 217(1), 81-86.

Croall, H. (1998). Crime and society in Britain. London: Longman. Henningfield, J. E, Fant, R.V., \& Wang, D. W. (2018). The abuse potential of kratom according the 8 factors of the controlled substances act: Implications for regulation and research. Psychopharmacology, 235(2), 235: 573. https://doi. org/10.1007/s00213-017-4813-4.

Jacques, S., \& Reynald, D. M. (2012). The offenders" oerspective on orevention:

Guarding against victimization and law enforcement. Journal of Research in Crime and Delinquency, 49(2), 269-294.

John, P. (2013). New directions in public policy: Theories of policy change and variation reconsidered. International Conference on Public Policy, Grenoble. Retrieved from http://www. icpublicpolicy.org/IMG/pdf/panel_84_1_peter

Julia Black. (2002). Critical reflections of regulations. LSE: London.

Kamarudin, A., \& Zoriah, A. (2012). Mitragyina speciosa used in the northern states of Malaysia: A cross sectional study. Journal of Ethnopharmacology, 141, 445-450.

Wilson, J. Q., \& Kelling, G. L. (1982) The police and neighbourhood safety "broken windows". The Atlantic Monthly, 3, 29-38.

Malaysia Poisons Act 1952 and Regulation (Act 366). Kuala Lumpur: ILBS.

Polinsky, A. M., \& Shavell, S. (1997). On the disutility and discounting of imprisonment and the Theory of Deterrence. NBER Working Papers 6259. National Bureau of Economic Research, Cambridge, MA.

Polinsky, A. M. (2005). The theory of public enforcement of law, NER working papers 11780, National Bureau of Economic Research, Cambridge, MA. 
Prozialeck, W. C., Jateen, K. J., \& Shridhar, V. A. (2012). Pharmacology of kratom: An emerging botanical agent with stimulant, analgesic and opioid-like effects. Journal of the American Osteopathic Association, 112(12), 792-799.

Richards, J. F. (2001). Opium and the British empire: The Royal Commisssion of 1895. Retrieved from http://www.drugpolicy. org/docuploads/opium_indiapdf.

Robertson, I. (1989) Society: A brief introduction. New York: Worth Publishing.

Rosenbaum, C. D., Carreiro, S. P., \& Babu, K. M. (2012). Here today, gone tomorrow ... and back again? A review of herbal marijuana alternatives (K2, Spice), synthetic cathinones (bath salts), kratom, salvia divinorum, methoxemine, and piperazines. J. Med. Toxicol., 8(1), 15-32.

Samihah, K., Siti Alida, J. A., \& Rusniah, A. (2018). Tumbuhan ketum di Malaysia: Prospek dan cabaran. Sintok: UUM Press.

Samihah, K., Siti Alida, J. A., \& Rusniah, A. (2015). Youth and kratom abuse in Kedah and Perlis. Proceeding International Conference on Innovation and Sustainability.

Samihah, K., Siti Alida, J. A., \& Rusniah, A. (2014). Report for AADK on misuse of kratom

in Northern Malaysia: Issues and solution. Sintok: Universiti Utara Malaysia.

Siegel, L. J. (2006). Criminology: Theories, patterns, \& typologies (9th ed.). Belmont, CA: Wadsworth Publishing.

Suwanlert, S. (1975). A study of kratom eaters in Thailand. Bulletin on Narcotics, 27(3), 21-27.

Swogger, M. T., Hart, E., Erowid, F., Erowid, E., Trabold, N., Yee, K., Parkhurst, K. A., Priddy,

B. M., \& Walsh, Z. (2015). Experiences of kratom users: A qualitative qnalysis. Journal of Psychoactive Drugs. DOI: 10.1080/02791072.2015.1096434.

Tanguay, P. (2011). Kratom in Thailand: Decriminalisation and community control?

Legislative Reform of Drug Policies, 13, 1-16.

Thuan, L. C. (1957). Addiction to mitragynine speciosa. Proceeding of Alumni Association, University of Malaya, pp. 322-324.

Walker, S. (1977). A critical history of police reform: The emergence of professionalism. Lexington, MT: Lexington Books. 